\title{
EFFECT OF DEPOSITION TIME ON NANOCOLUMNAR TIZrN FILMS GROWN BY REACTIVE MAGNETRON CO-SPUTTERING WITH THE OAD TECHNIQUE
}

\author{
VPLIV ČASA NANAŠANJA NANOSTEBRIČASTIH TiZrN FILMOV \\ Z OAD TEHNIKO IN HKRATNIM REAKTIVNIM \\ MAGNETRONSKIM NAPRŠEVANJEM
}

\author{
Wuttichai Phae-ngam ${ }^{1 *}$, Chanunthorn Chananonnawathorn², Tossaporn Lertvanithphol'2, \\ Benjarong Samransuksamer ${ }^{2}$, Mati Horprathum ${ }^{2}$, Teeranon Chaiyakun ${ }^{3}$ \\ ${ }^{1}$ Physics Program, Phranakhon Rajabhat University, Bangkok 10220, Thailand \\ ${ }^{2}$ National Electronics and Computer Technology Center, Pathumthani 12120, Thailand \\ ${ }^{3}$ Industrial Electrical Technology Program, Faculty of Industrial Technology, Valaya Alongkorn Rajabhat University under the \\ Royal Patronage, Pathumthani 13180, Thailand
}

Prejem rokopisa - received: 2019-08-17; sprejem za objavo - accepted for publication: 2020-09-24

doi:10.17222/mit.2019.189

Well-separated inclined nanocolumnar TiZrN films were grown on silicon-wafer substrates by reactive magnetron co-sputtering with the oblique-angle-deposition (OAD) technique. The crystal structure, thickness, morphology and chemical composition of the prepared TiZrN films were investigated with the X-ray diffraction technique at the grazing-incidence angle (GIXRD), field-emission scanning electron microscopy (FE-SEM) and energy dispersive X-ray spectroscopy (EDS). The length, diameter and tilt angle of the nanocolumnar TiZrN films were evaluated. The microstructure and chemical composition were analyzed with transmission electron microscopy (TEM). The results indicated that the film crystallinity and physical morphology were influenced by the deposition time due to the self-annealing effect, which occurred during the nanocolumnar growth. Moreover, the hardness and surface wettability of the TiZrN films were studied using a nanoindentater and the water-contact-angle method, respectively. It was found that the hardness and hydrophobic surface of the TiZrN films decreased with the increasing deposition time.

Keywords: TiZrN film, OAD, reactive co-sputtering, self-annealing effect

Avtorji v članku opisujejo rast dobro medsebojno ločenih in nagnjenih nanostebričastih TiZrN filmov na silicijevih rezinah med postopkom istočasnega reaktivnega magnetronskega naprševanja s tehniko poševno kotnega nanosa oz. depozicije (OAD, angl.: oblique angle deposition). Kristalno strukturo izdelanih TiZrN filmov, njihovo debelino in morfologijo so analizirali z rentgensko difrakcijo (XRD), rentgensko tehniko GIXRD (angl.: grazing-incidence angle X-ray diffraction), vrstičnim elektronskim mikroskopom (FE-SEM) in spektroskopijo na osnovi energijske disperzije rentgenskih žarkov (EDS). Avtorji so ocenili dolžino, premer in nagib nanostebričkov izdelanih tankih plasti (filmov) na osnovi TiZrN. Njihovo mikrostrukturo in kemijsko sestavo so analizirali s presevnim elektronskim mikroskopom (TEM). Rezultati analiz kažejo, da so izdelani filmi kristalinični in njihova morfologija je odvisna od časa naprševanja zaradi učinka samomehčanja, ki poteka med rastjo nanostebričkov. Nadalje so avtorji določali trdoto in omakanjem površine TiZrN filmov z metodama nanoindentacije in metodo merjenja kota omakanja. Na osnovi izvedenih analiz avtorji ugotavljajo, da se trdota in hidrofobnost površine TiZrN filmov zmanjšuje s podaljševanjem časa naprševanja.

Ključne besede: TiZrN film, OAD, reaktivno istočasno naprševanje, učinek samo-popuščanja (samo-mehčanja)

\section{INTRODUCTION}

Recently, nanostructured materials have attracted considerable attention due to their unique properties and potentials in various applications such as nanoelectronics and nanophotonic devices. Nanostructured materials have been synthesized with numerous techniques, i.e., vapor-liquid-solid deposition, ${ }^{1-3}$ chemical vapor deposition $^{4-6}$ and physical vapor deposition. ${ }^{7-11}$ Physical vapor deposition (PVD) carried out with the oblique angle deposition (OAD) technique is a suitable method for preparing one-dimensional nanostructures as well as nanocolumnar ones where the orientation of an isolated

*Corresponding author's e-mail:

wuttichai@pnru.ac.th (Wuttichai Phae-ngam) nanocolumnar growth can be controlled with the self-shadowing effect and limited adatom diffusion. ${ }^{12-14}$ Considering these PVD methods, the magnetron sputtering has been used as a promising technique as it allows an easy adjustment of deposition parameters and it is applicable at laboratory and industrial scales. Moreover, several materials, for example, metal, metal oxide/nitride can be prepared to provide for a nanocolumnar film with a well-controlled structure and film crystallinity realized by magnetron sputtering with the OAD technique. Recently, the OAD technique has been developed for bimetallic alloys and ternary oxides/nitrides realized by magnetron sputtering with an alloy target. ${ }^{15,16}$ A sputtering target requires a specially prepared alloy, or powder target, and the composition of the film depends on the elements in the target. Magnetron co-sputtering is a promis- 
ing method, which can help us control the composition of the films. Only few works reported on magnetron co-sputtering at an oblique angle used for preparing a nanostructure bimetallic alloy. ${ }^{17,18}$ Nevertheless, the preparation of a ternary metal nitride with reactive magnetron co-sputtering using the OAD technique was successful and reported by our group. ${ }^{19}$ Significant findings were reported including the effects of the crucial deposition conditions such as the sputtering power, structure and morphology of nanocolumnar films.

In this work, we focus on titanium zirconium nitride ( TiZrN) because this ternary metal nitride has gained much attention as due to its superior mechanical properties, including better corrosion resistance, good toughness, low electrical resistivity, biocompatibility and high thermal stability. Moreover, a systematic research of the nanoscale property of the nanocolumnar TiZrN films provided a significant and meaningful contribution to the development of novel advanced applications in the future. Thus, in this present study, the effects of the deposition time on the film thickness, crystallinity, morphology, composition, surface wettability and hardness of the nanocolumnar TiZrN films prepared by reactive magnetron co-sputtering with the OAD technique were presented and discussed.

\section{EXPERIMENTAL PART}

Figure 1a shows a schematic of the reactive magnetron co-sputtering set-up using the OAD technique. Metallic titanium (Ti with a $99.99 \%$ purity) and zirconium (Zr with a $96.9 \%$ purity) with a diameter of 2 inches were used as the sputtering targets. The substrate was a Si wafer (100) and it was placed at an oblique angle with respect to the direction normal to the target. The targets were focused on the center of the substrate $\left(d_{\text {Ti-sub }}=50\right.$ $\mathrm{mm}$ and $d_{\mathrm{Zr} \text {-sub }}=50 \mathrm{~mm}$ ) in a confocal configuration, making fixed angles of $88^{\circ}\left(\alpha_{1}\right)$ and $85^{\circ}\left(\alpha_{2}\right)$ for the Ti target and $\mathrm{Zr}$ target, respectively, with respect to the plane of the substrate holder. The deposition flux approached the stationary substrate at an oblique angle $(\alpha)$ relative to the substrate normal, referred to the incident angle, producing well-isolated nanocolumnar films due to the self-shadowing effect and limited adatom diffusion as shown in Figure $\mathbf{1 b}$.

Prior to the installation of the silicon-wafer substrates in the vacuum chamber, they were cleaned with an ultrasonic cleaner in acetone, isopropanol and then with DI water. The base pressure of the deposition chamber was about $3 \times 10^{-6}$ Torr. The operating pressure was 5 mTorr, controlled by a pressure gauge, whereas mass-flow controllers regulated the high-purity argon (Ar with a 99.999 $\%$ purity) and nitrogen $\left(\mathrm{N}_{2}\right.$ with a $99.999 \%$ purity) with flow rates of $15 \mathrm{sccm}$ and $20 \mathrm{sccm}$, respectively. The DC sputtering powers applied to the $\mathrm{Ti}$ and $\mathrm{Zr}$ targets were kept constant at $225 \mathrm{~W}$ and $250 \mathrm{~W}$, respectively. The deposition chamber was evacuated by a rotary pump
(ALCATEL) and turbo-molecular pump (Shimazu, TMP-803-LM). Prior to the deposition, in-situ plasma cleaning with Ar plasma ions was performed at a pressure of 10 mTorr for $15 \mathrm{~min}$ and a substrate bias of -150 $\mathrm{V}$ in order to remove any residue from the $\mathrm{Si}$ substrate surfaces. The experiment was carried out with different deposition times of $(60,120,180$ and 240) min.

The crystal structure of the films was characterized with X-ray diffraction at the grazing-incidence angle (GIXRD; RigakuTtraz III), with the $\mathrm{Cu} K_{\alpha}$ radiation operating at $50 \mathrm{kV}, 300 \mathrm{~mA}$. The measurements were recorded in a $2 \theta$ range of $20-70^{\circ}$ with a scanning speed of $2^{\circ}$ per min and a $2 \theta$ step of $0.02^{\circ}$. The film thickness and morphology were observed with field-emission scanning electron microscopy (FE-SEM; Hitachi, S8080) at an operating voltage of $10 \mathrm{kV}$.

The microstructure of the TiZrN films was analyzed with high-resolution transmission electron microscopy (HRTEM; JEOL JEM-2010) performed at an accelerating voltage of $200 \mathrm{kV}$. The TiZrN films prepared on Si were scrapped off the $\mathrm{Si}$ substrate surface with a diamond cutter and nanorod powders of the TiZrN films were obtained. The powders were dispersed in ethanol and dropped onto carbon-coated copper grids for a microstructure analysis with TEM. When observing a
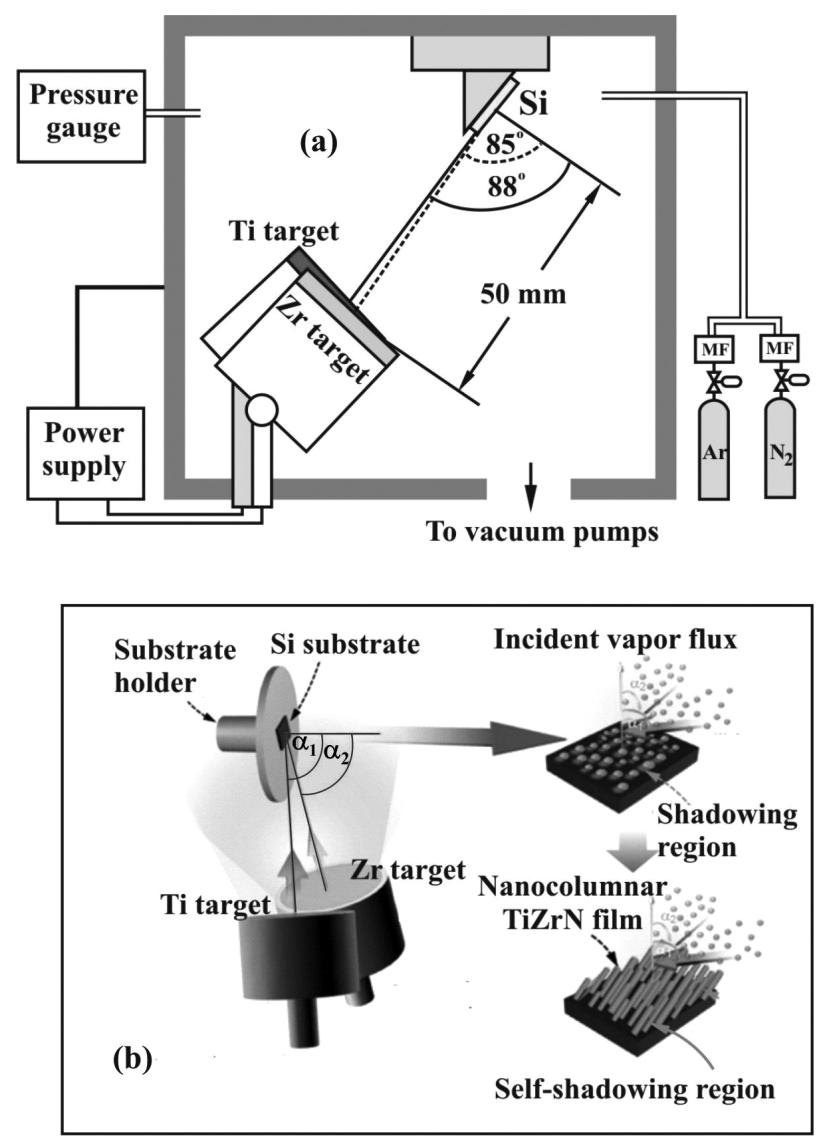

Figure 1: a) Schematic of the reactive magnetron co-sputtering set-up using the OAD technique; b) diagram showing the growth of nanocolumnar TiZrN films 
nanorod image, we tried to find an area with only one rod in the field of view.

The hardness of the TiZrN films prepared on the silicon-wafer substrate was investigated with a nanoindenter (CSM Instrument, $\mathrm{NHT}^{2}$ ) with a diamond Berkovichtype head and the applied load was in a range of $0.6-1.2 \mathrm{mN}$. A suitable load of indentation was selected based on the indent depth, which should be equal to $10 \%$ of the total film thickness to avoid the influence of the substrate on the film layer. The loading and unloading were chosen to be linearly increasing and decreasing with a time of $30 \mathrm{~s}$ for both. The hardness was calculated using the Oliver-Pharr method. ${ }^{20,21}$ The surface wettability behavior of the films was examined at a water

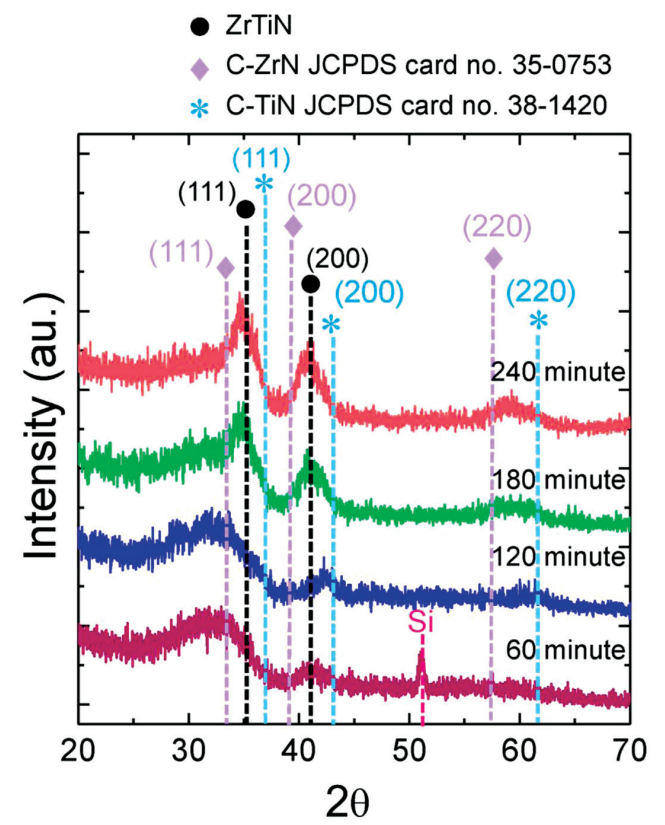

Figure 2: GIXRD patterns of the TiZrN films prepared at different deposition times

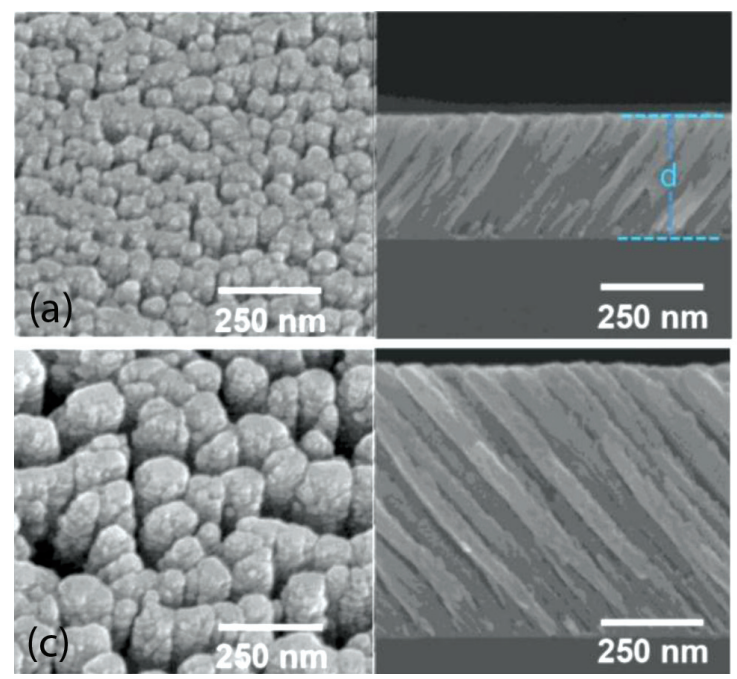

contact angle (Ramé-Hart Instrument, Model 250) in ambient air $\left(25^{\circ} \mathrm{C}\right.$, a relative humidity of $\left.50 \%\right)$.

\section{RESULTS AND DISCUSSION}

Figure 2 shows the GIXRD patterns of the TiZrN films prepared at different deposition times of $(60,120$, 180 and 240) $\mathrm{min}$. Two major peaks corresponding to the (111) and (200) planes of the NaCl-type crystalline structure were observed. It is clearly seen that the reflection of TiZrN peaks appeared between TiN (JCPDS: no. 35-0753) and ZrN (JCPDS: no. 38-1420). The result indicates that the TiZrN films prepared at $60 \mathrm{~min}$ and 120 min show a broad reflection of the (111) peak. When the deposition time was increased to $240 \mathrm{~min}$, the peaks became more intense and sharper. A longer deposition time results in a localized heating treatment of the substrate surface and enhancement of the film crystallinity. ${ }^{9}$

Figure 3 shows top-view and cross-section FE-SEM images of the TiZrN films deposited at different deposition times. It can be clearly observed that all the prepared films exhibit a porous and well-separated, inclined nanocolumnar growth. The top-view FE-SEM images show more porosity with large spaces between nanocolumnar growths as the deposition time increases. The cross-section FE-SEM images reveal the evolution of an inclined nanocolumnar growth, whose thickness $(d)$, length and incline angle $(\beta)$ increase as a result of the enhancement of the shadowing effect during the film growth achieved with the OAD technique.

Generally, the inclined nanocolumnar growth process might be divided into two stages as shown in Figure $\mathbf{3 b}$. In the early stage, the cluster of atoms were randomly deposited on the substrate, forming the initial nucleation site. Since the next atom cluster from the vapor flux at the oblique angle could not reach the shadow areas of the initial cluster atom, the adatoms accumulated only on the taller island. This preferential growth dynamic allowed

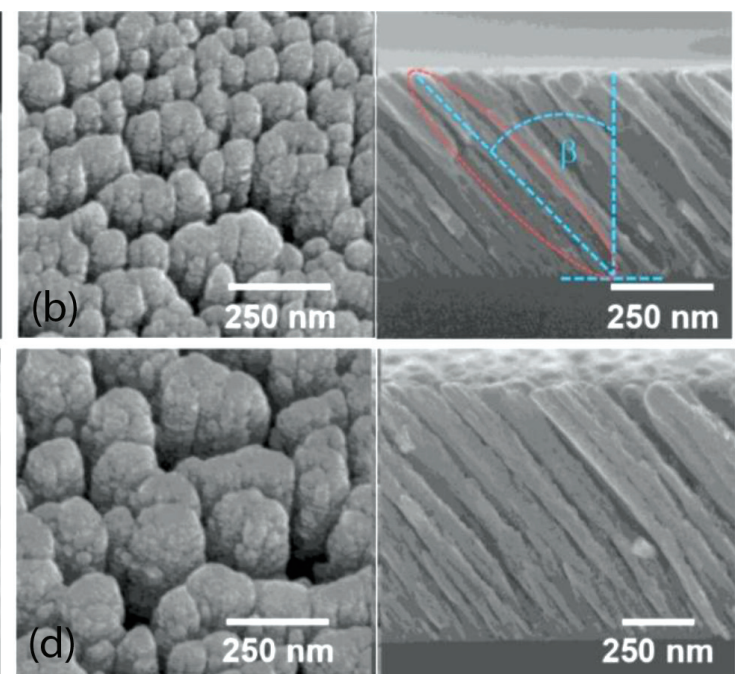

Figure 3: Top-view and cross-section FE-SEM images of TiZrN films deposited at (60, 120, 180 and 240) min 

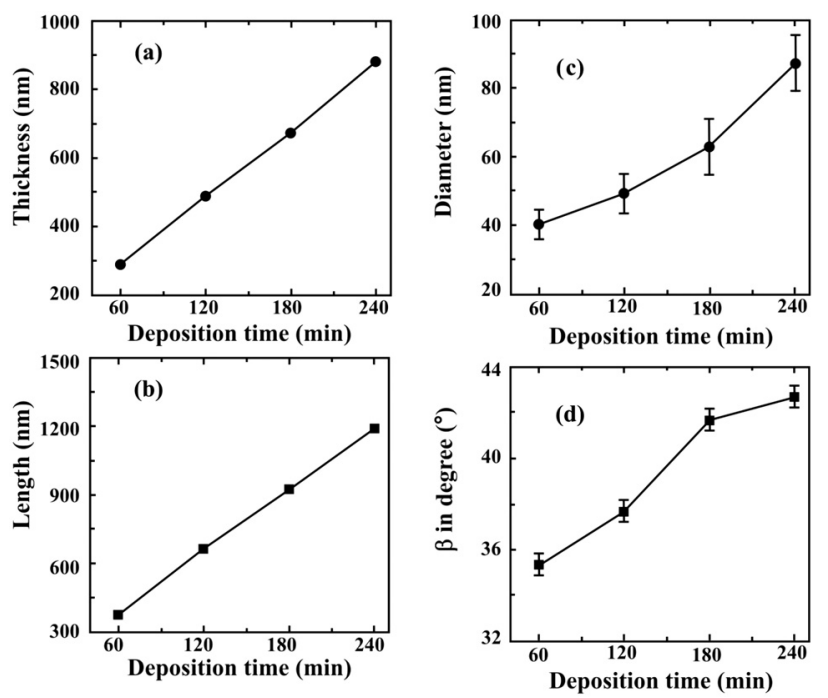

Figure 4: a) Thickness, b) length, c) diameter and d) tilt angle $(\beta)$ of the nanocolumnar TiZrN films deposited at different deposition times

the formation of a nanocolumnar structure tilted to the incoming-flux direction. ${ }^{7-10}$ Furthermore, the thickness (d) and length of a nanocolumn were influences by the deposition time. The diameter of a nanocolumn was controlled by the atomic mobility of the material, which was affected by the material property and deposition condition as well as the temperature during the film deposition. ${ }^{9}$ Note that the nanocolumn tilt angle was affected by the deposition angle and surface mobility of the adatoms on the surface of the substrate.

In order to make good measurements of the obtained nanocolumnar TiZrN films, the thickness, diameter, length and nanocolumnar tilt angle $(\beta)$ at different deposition times were evaluated and plots of these values as a function of deposition time are shown in Figure 4.

It is seen that the thickness and length increase linearly with the increase in the deposition time. The diameter of the nanocolumnar growth was also found to increase with the increasing deposition time. With the increasing thickness and length of the nanocolumnar growth, the number of the nanocolumns per unit area was reduced significantly as the deposition time increased (as seen in Figure 3), which was the result of some nanocolumnar growth entering the shadow area of the adjacent nanocolumn that could not grow up, and the area of the remaining nanocolumn exposed to the incoming adatom flux was increased with the increasing length. Furthermore, the nanocolumnar growth became large regarding its diameter as a result of the self-annealing effect. The increase in the deposition time led to a merged nanocolumnar growth, with a diameter varying in a range of $40-87 \mathrm{~nm}$. This could be attributed to the surface-diffusion effect where a longer deposition time eventually caused an increase in the ambient temperature that enhanced the adatom mobility ${ }^{9,22}$. Moreover, the nanocolumnar growth of the TiZrN films tend to bend with the increasing film thickness. The tilt angle $(\beta)$ of the nanocolumn growth with respect to the silicon substrate was increased from $35^{\circ}$ to $42^{\circ}$ which is slightly lower than the theoretical value $(\beta=57.84-59.15$ for $\alpha=$ $85-88^{\circ}$ as predicted by the cosine rule $(2 \sin (\alpha-\beta)=1-$ $\cos \alpha)$ ). However, the difference between the theoretical and experimental result values may have been caused by all the adatoms produced by co-sputtering that did not have the same direction so that the column angle from the experimental data is lower than that from the calculation data. There is variation in the deposition parameters, i.e., the operating pressure, substrate temperature and preferred crystallinity of the deposited material ${ }^{23}$. In addition, the results of the EDS element analysis (not shown here) confirmed that the nanocolumnar TiZrN films contain $\mathrm{Ti}, \mathrm{Zr}$ and $\mathrm{N}$ with the averaged contents of $\sim 27.0, \sim 24.7$ and $\sim 48.3$ at.\% respectively, at all deposition times.

Figure 5 shows bright-field TEM images of individual nanocolumnar TiZrN films prepared at 60 and 240 min. All the nanocolumnar films exhibit high porosity, which many nanoridge structures present along a columnar surface. The formation of a nanoridge structure grown with OAD was also observed in the literature. ${ }^{10}$ Moreover, the nanocolumnar TiZrN films deposited at 60 min are clearly observed to have a diameter of $\sim 55 \mathrm{~nm}$ and length of $\sim 320 \mathrm{~nm}$. The TEM image of the film deposited at 240 min shows a $\sim 96 \mathrm{~nm}$ diameter and $\sim 1105$ nm length, which are in good agreement with the FE-SEM results. Further analysis of the crystallinity of the nanocolumnar film from the selective-area electron-diffraction pattern (SAED) shows a polycrystalline structure mixed with an amorphous structure after the
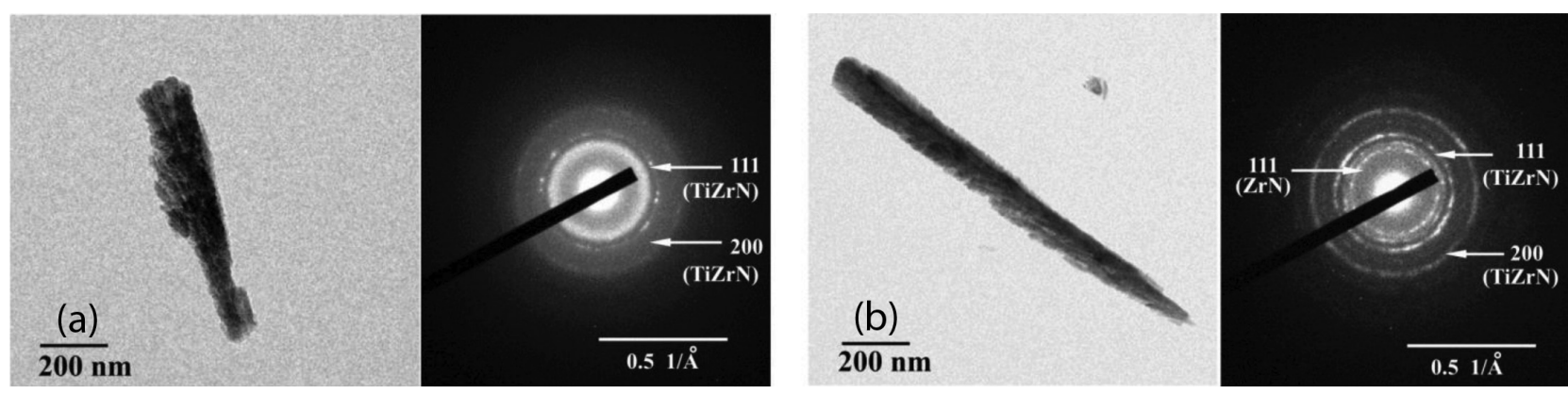

Figure 5: Bright-field TEM images and SAED patterns of the nanocolumnar TiZrN films prepared at: a) 60 and b) $240 \mathrm{~min}$ 

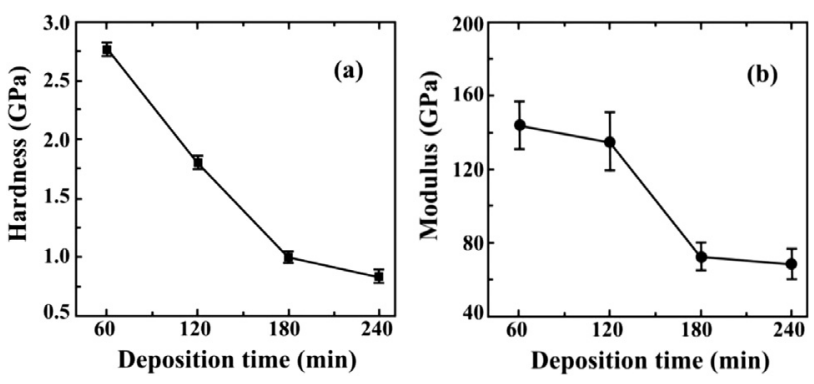

Figure 6: Mechanical properties of the nanocolumnar TiZrN films as a function of the deposition time

60-min deposition time. After the 240-min deposition time, the nanocolumnar film was found to be highly crystalline. Therefore, the SAED results are in good agreement with GIXRD.

Figure 6 shows the hardness and modulus of the nanocolumnar TiZrN films as a function of deposition times. Note that each reported hardness and modulus value was the average of 5 indentations. One can see that the hardness and modulus diminished with an increase in the deposition time, which was probably the cause of the porosity degree of the nanocolumnar structure, as indicated by the FE-SEM result (Figure 3). During the co-sputtering process with a longer deposition time, the substrate is heated by the energy of the particles impinging on the film surface and the thermal energy induced by localized substrate heating, hence enhancing the adatom mobility, which leads to the merging of sub-nanocolum and elongated void network. Thus, the overall mass density decreased, which led to a lower hardness and Young's modulus. ${ }^{24-26}$ In addition, the results confirm that our nanocolumnar TiZrN films show a lower hardness value than that of a dense TiZrN film

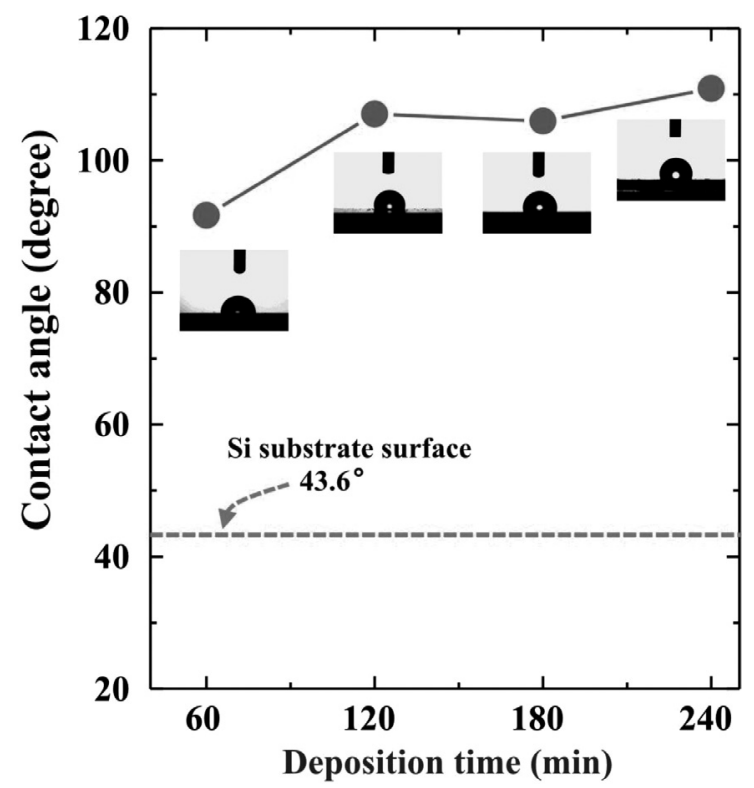

Figure 7: Water contact angle of the Si-substrate surface and the nanocolumnar TiZrN films deposited on Si substrates at various deposition times
(28-36 Gpa). ${ }^{27,28}$ One can suppose that the highly porous structure of the film layer provides a significant contribution to the large decrease in the film density, which resulted in a decrease of the hardness.

Figure 7 shows the wettability of the nanocolumnar TiZrN films deposited at different deposition times. The wettability was characterized with a water-contact-angle measurement producing photographs of water droplets on the silicon-wafer substrate surfaces. The results indicate that all the nanocolumnar films have a hydrophobic surface. The results show that the silicon-wafer substrate, like the reference samples, had a small water-contact angle of $43.6^{\circ}$. The water-contact angle for the nanocolumnar TiZrN films deposited at 60 min was $91^{\circ}$, which increased to a value of $110^{\circ}$ for the nanocolumnar films deposited at $240 \mathrm{~min}$ due to the increase in the surface roughness. Therefore, the nanocolumnar TiZrN films are expected to perform well in self-cleaning applications.

\section{CONCLUSIONS}

In this study, we successfully deposited nanocolumnar TiZrN films on silicon-wafer substrates with reactive co-magnetron sputtering using the oblique-angle deposition technique. Longer deposition times clearly indicated higher crystallinity with large diameters of the nanorods due to the self-annealing effect. Moreover, the nanocolumnar TiZrN films exhibited low hardness. In addition, the results indicated that the increasing deposition time resulted in an increase in the nanocolumnar tilt angle and also in the roughness of the surface, showing super-hydrophobicity. Finally, the present approach allowed us to demonstrate a promising technique for preparing nanocolumnar ternary films by reactive co-magnetron sputtering with OAD which is important for future nanodevice applications.

\section{Acknowledgment}

The authors would like to thank the Pharanakorn Rajabhat University for the financial support.

\section{REFERENCES}

${ }^{1}$ A. Klamchuen, M. Suzuki, K. Nagashima, H. Yoshida, M. Kanai, F. Zhuge, Y. He, G. Meng, S. Kai, S. Takeda, T. Kawai, T. Yanagida, Rational concept for designing vapor-liquid-solid growth of single crystalline metal oxide nanowires, Nano Lett., 15 (2015) 10, 6406-6412, doi:10.1021/acs.nanolett.5b01604

${ }^{2}$ A. Klamchuen, T. Yanagid, M. Kanai, K. Nagashima, K. Oka, S. Rahong, M. Gang, M. Horprathum, M. Suzuki, Y. Hidaka, S. Kai, T. Kawai, Study on transport pathway in oxide nanowire growth by using spacing-controlled regular array, Appl. Phys. Lett., 99 (2011), 193105, doi:10.1063/1.3660246

${ }^{3}$ K. Nagashima, T. Yanagida, K. Oka, M. Kanai, A. Klamchuen, S. Rahong, G. Meng, M. Horprathum, B. Xu, F. Zhuge, Y. He, B. H. Park, T. Kawai, Prominent thermodynamical interaction with surroundings on nanoscale memristive switching of metal oxides, Nano Lett., 12 (2012) 11, 5684-5690, doi:10.1021/n1302880a 
${ }^{4}$ X. M. Cai, F. Ye, S. Y. Jing, D. P. Zhang, E. Q. Xie, A systematic study of chemical vapor deposition growth of InN, Appl. Surf. Sci., 255 (2008), 2153-2158, doi:10.1016/j.apsusc.2008.07.051

${ }^{5} \mathrm{~K}$. Teker, Density and morphology adjustments of gallium nitride nanowires, Appl. Surf. Sci., 283 (2013), 1065-1070, doi:10.1016/ j.apsusc.2013.07.069

${ }^{6}$ L. Yu, Y. Lv, P. Liu, X. Yu, Synthesis of rhombic and triangular cross-sectional AlN nanorods on Si substrate via thermal CVD, Mater. Lett., 65 (2011) 10, 1499-1502, doi:10.1016/j.matlet.2011. 02.052

${ }^{7}$ M. Horprathum, T. Srichaiyaperk, B. Samransuksamer, A. Wisitsoraat, P. Eiamchai, S. Limwichean, C. Chananonnawathron, K. Aiempanakit, N. Nuntawong, V. Patthanasettakul, C. Oros, S. Porntheeraphat, P. Songsiriritthigul, H. Nakajima, A. Tuantranont, P. Chindaudom, Ultrasensitive hydrogen sensor based on Pt-decorated $\mathrm{WO}_{3}$ nanorods prepared by glancing-angle dc magnetron sputtering, ACS Appl. Mater. Interfaces, 6 (2014), 22051-22060, doi:10.1021/ am505127g

${ }^{8}$ M. Horprathum, K. Limwichean, A. Wisitsoraat, P. Eiamchai, K. Aiempanakit, P. Limnonthakul, N. Nuntawong, V. Patthanasettakul, A. Tuantranont, P. Chindaudom, $\mathrm{NO}_{2}$ - sensing properties of $\mathrm{WO}_{3}$ nanorods prepared by glancing angle DC magnetron sputtering, Sens. Actuators B, 176 (2013), 685-691, doi:10.1016/j.snb.2012. 09.077

${ }^{9}$ P. Nuchuaya, T. Chaikeereea, M. Horprathum, N. Mungkung, N. Kasayapanand, C. Oros, S. Limwichean, N. Nuntawong, C. Chananonnawathorn, V. Patthanasettakul, P. Muthitamongkol, B. Samransuksamer, S. Denchitcharoen, A. Klamchuen, C. Thanachayanont, P. Eiamchai, Engineered omnidirectional antireflection ITO nanorod films with super hydrophobic surface via glancing-angle ion-assisted electron-beam evaporation deposition, Curr. Appl. Phys., 17 (2017), 222-229, doi:10.1016/j.cap.2016.11.018

${ }^{10}$ C. Oros, M. Horprathum, A. Wisitsoraat, T. Srichaiyaperk, B. Samransuksamer, S. Limwichean, P. Eiamchai, D. Phokharatkul, N. Nuntawong, C. Chananonnawathron, V. Patthanasettakul, A. Klamchuen, J. Kaewkhao, A. Tuantranont, P. Chindaudom, Ultrasensitive $\mathrm{NO}_{2}$ sensor based on vertically aligned $\mathrm{SnO}_{2}$ nanorods deposited by DC reactive magnetron sputtering with glancing angle deposition technique, Sens. Actuators B, 223 (2016), 936-945, doi:10.1016/j.snb.2015.09.104

${ }^{11}$ B. Samransuksamer, M. Horprathum, T. Jutarosaga, A. Kopwitthaya, S. Limwichean, N. Nuntawong, C. Chananonnawathorn, V. Patthanasettakul, P. Muthitamongkol, A. Treetong, A. Klamchuen, A. Leelapojanaporn, C. Thanachayanont, P. Eiamchai, Facile method for decorations of $\mathrm{Au}$ nanoparticles on $\mathrm{TiO}_{2}$ nanorod arrays toward high-performance recyclable SERS substrates, Sens. Actuators B, 277 (2018), 102-113, doi:10.1016/j.snb.2018.08.136

${ }^{12}$ N. Nuntawong, P. Eiamchai, K. Wong-ek, M. Horprathum, K. Limwichean, V. Patthanasettakul, P. Chindaudom, Shelf time effect on SERS effectiveness of silver nanorod prepared by OAD technique, Vacuum, 88 (2013), 23-27, doi:10.1016/j.vacuum.2012. 08.006

${ }^{13}$ A. Siad, A. Besnard, C. Nouveau, P. Jacque, Critical angles in DC magnetron glad thin films, Vacuum, 131 (2016), 305-311, doi:10.1016/j.vacuum.2016.07.012

${ }^{14}$ A. Barranco, A. Borras, A. R. Gonzalez-Elipe, A. Palmero, Perspectives on oblique angle deposition of thin films: From fundamentals to devices, Prog. Mater Sci., 76 (2016), 59-153, doi:10.1016/j.pmatsci. 2015.06.003
${ }^{15}$ A. R. Shetty, A. Karimi, M. Cantoni, Effect of deposition angle on the structure and properties of pulsed-DC magnetron sputtered TiAlN thin films, Thin Solid Films, 519 (2011), 4262-4270, doi:10.1016/j.tsf.2011.02.090

${ }^{16}$ A. R. Shetty, A. Karimi, Texture mechanisms and microstructure of biaxial thin films grown by oblique angle deposition, Phys. Status Solidi B, 249 (2012) 8, 1531-1540, doi:10.1002/pssb.201248010

${ }^{17}$ R. E. Beainou, N. Martin, V. Potin, P. Pedrosa, M. A. P. Yazdi, A. Billard, Correlation between structure and electrical resistivity of W-Cu thin films prepared by GLAD co-sputtering, Surf. Coat., 313 (2017), 1-7, doi:10.1016/j.surfcoat.2017.01.039

${ }^{18}$ R. E. Beainou, N. Martin, V. Potin, P. Pedrosa, M. A. P. Yazdi, A. Billard, W-Cu sputtered thin films grown at oblique angles from two sources: Pressure and shielding effects, Surf. Coat. Technol., 343 (2018), 153-159, doi:10.1016/j.surfcoat.2017.09.062

${ }^{19}$ W. Phae-ngam, M. Horprathum, C. Chananonnawathorn, T. Lertvanithphol, B. Samransuksamer, P. Songsiriritthigul, H. Nakajima, S. Chaiyakun, Oblique angle deposition of nanocolumnar TiZrN films via reactive magnetron co-sputtering technique: The influence of the Zr target powers, Curr. Appl. Phys., 19 (2019), 894-901, doi:10.1016/j.cap.2019.05.002

${ }^{20}$ W. C. Oliver, G. M. Pharr, An improved technique for determining hardness and elastic modulus using load and displacement sensing indentation experiments, J. Mater. Res., 7 (1992), 1564-1583, doi:10.1557/JMR.1992.1564

${ }^{21}$ W. C. Oliver, G. M. Pharr, Measurement of hardness and elastic modulus by instrumented indentation: Advances in understanding and refinements to methodology, J. Mater. Res., 19 (2004), 3-20

${ }^{22}$ C. Patzig, A. Miessler, T. Karabacak, B. Rauschenbach, Arbitrarily shaped Si nanostructures by glancing angle ion beam sputter deposition, Phys. Status Solidi B, 247 (2010), 1310-1321, doi:10.1002/ pssb.200945525

${ }^{23}$ P. M. Martin, Handbook of Deposition Technologies for Films and Coatings: Science, Applications and Technology, Chapter 13, Glancing Angle Deposition, 2010, 621-678

${ }^{24}$ J. Lintymer, J. Gavoille, N. Martin, J. Takadoum, Glancing angle deposition to modify microstructure and properties of sputter deposited chromium thin films, Surface and Coatings Technology, 174-175 (2003), 316-323, doi:10.1016/S0257-8972(03)00413-4

${ }^{25}$ A. R. Shetty, A. Karimi, Texture mechanisms and microstructure of biaxial thin films grown by oblique angle deposition, Phys. Status Solidi B, 249 (2012) 8, doi.10.1002/pssb.201248010

${ }^{26}$ A. R. Shetty, A. Karimi, M. Cantoni, Effect of deposition angle on the structure and properties of pulsed-DC magnetron sputtered TiAlN thin films, Thin Solid Films, 519 (2011), 4262-4270, doi:10.1016/j.tsf.2011.02.090

${ }^{27}$ Y. W. Lin, H. A. Chen, G. P. Yu, J. H. Huan, Effect of Bias on the Structure and Properties of TiZrN Thin Films Deposited by Unbalanced Magnetron Sputtering, Thin Solid Films, 618 (2016), 13-20, doi:10.1016/j.tsf.2016.05.021

${ }^{28}$ E. W. Niu, L. Li, G. H. Lv, H. Chen, X. Z. Li, X. Z.Yang, S. Z.Yang, Characterization of Ti-Zr-N films deposited by cathodic vacuum arc with different substrate bias, Applied Surface Science, 254 (2008) 13, 3909-3914, doi:10.1016/j.apsusc.2007.12.022 